\title{
Effect of DEM data resolution on SWAT output uncertainty
}

\author{
I. Chaubey, ${ }^{1 *}$ A. S. Cotter, ${ }^{1}$ T. A. Costello ${ }^{2}$ and T. S. Soerens ${ }^{2}$ \\ ${ }^{1}$ Department of Biological and Agricultural Engineering, University of Arkansas, Fayetteville, AR 72701, USA \\ ${ }^{2}$ Department of Civil Engineering, University of Arkansas, Fayetteville, AR 72701, USA
}

\begin{abstract}
:
This paper describes the effect of DEM data resolution on predictions from the SWAT model. Measured hydrologic, meteorological, watershed characteristics and water quality data from Moores Creek watershed (near Lincoln, AR, USA) were used in the simulation. The effect of input data resolution was evaluated by running seven scenarios at increasing DEM grid sizes $(30 \times 30 \mathrm{~m}, 100 \times 100 \mathrm{~m}, 150 \times 150 \mathrm{~m}, 200 \times 200 \mathrm{~m}, 300 \times 300 \mathrm{~m}, 500 \times 500 \mathrm{~m}$, $1000 \times 1000 \mathrm{~m}$ ). The model was calibrated on an annual basis for flow, $\mathrm{NO}_{3}-\mathrm{N}$ and total $\mathrm{P}$ using $30 \times 30 \mathrm{~m}$ DEM data. The predicted output at the calibrated scale was used to evaluate output accuracy for the remaining input resolutions. Results of this study showed that DEM resolution affects the watershed delineation, stream network and sub-basin classification in the SWAT model. A decrease in DEM resolution resulted in decreased stream flow and $\mathrm{NO}_{3}-\mathrm{N}$ load predictions. However, model predicted total $\mathrm{P}$ did not always decrease with DEM resolution. Results of this study indicate that the choice of input DEM resolution depends on the watershed response of interest. Minimum DEM data resolution ranged from 100 to $200 \mathrm{~m}$ to achieve less than $10 \%$ error in SWAT output for flow, $\mathrm{NO}_{3}-\mathrm{N}$ and TP predictions. Copyright (C) 2005 John Wiley \& Sons, Ltd.
\end{abstract}

KEY WORDS SWAT; DEM data resolution; output uncertainty

\section{INTRODUCTION}

Use of water quality models for estimating nonpoint source (NPS) pollutant loads from watersheds and for predicting stream response to various pollutant loading scenarios has increased significantly in recent years. Such modelling applications are used to identify 'hot spots' within a watershed where best management practices (BMPs) need to be implemented, or to evaluate the impact of various BMPs on water quality responses. The use of geographic information systems (GIS) has made possible distributed modelling incorporating spatially heterogeneous watershed information such as land use, elevation and soil data. However, an accompanying concern is the spatial scale at which any simulation model is assumed to be accurate, and the spatial scale at which both model input and field verification data should be collected. Because GIS-based water quality modelling results are sensitive to the spatial resolution of the input data (Cho and Lee, 2001; Moore et al., 1991; Piwowar and LeDrew, 1990; Wolock and McCabe, 1995; Wolock and Price, 1994), it is important to assess the effect of spatial resolution of input data on model accuracy.

Sources of uncertainty in model predictions can be classified into two groups (Troutman, 1983): (1) model errors with correct input and (2) error due to erroneous input. Even though the effect of erroneous input data on model predictions is relatively well documented (e.g., Chaubey et al., 1999; Faures et al., 1995; Goodrich et al., 1995; Shah et al., 1996 among others), little information is currently available to quantify the effect of spatial input data resolution on model outputs. Wagenet and Hutson (1996) reported that even though use of GIS has greatly enhanced our capability to simulate watershed-scale water quality processes, the scale at

* Correspondence to: I. Chaubey, 203 Engineering Hall, University of Arkansas, Fayetteville, AR 72701, USA. E-mail: chaubey@uark.edu 
which GIS data, such as soil survey, elevation and land use, should be collected and used is a major concern and needs to be studied. The authors concluded that modelling results can be sensitive to the nature and quality of input variables at a given scale and that the interpretation of model output is limited to the resolution and quality of environmental data. Based on a modelling study to predict solute transport in soil media, Inskeep et al. (1996) concluded that model predictions based on input data sets with low spatial resolution may not accurately reflect transport processes occurring in situ. In a similar study, Wilson et al. (1996) concluded that model results to predict movement of pesticides in soils were most accurate when fine resolution input data were used. The model output errors significantly increased with a decrease in spatial resolution of input soil data.

This paper evaluates the effect of input digital elevation model (DEM) data resolution on the Soil and Water Assessment Tool (SWAT) model prediction uncertainty. The SWAT model has become widely accepted as an effective tool to predict the effects of watershed management on runoff, sediment, nutrients and pesticide yields (Arnold et al., 1993, 1998). The US EPA is using the SWAT model as a component in its programme (Better Assessment Science Integrating Point and Non-point Sources, BASINS) to aid in achieving the goals of the Clean Water Act.

\section{METHODS}

\section{SWAT model description}

The SWAT model is a watershed-scale, physically based distributed-parameter model developed to predict the impact of land management practices on hydrologic and water quality response of complex watersheds with heterogeneous soils and land use conditions (Arnold et al., 1998). The model partitions a watershed into subwatersheds and organizes input information for each subwatershed into the following categories: climate, hydrologic response units (HRUs), ponds/wetlands, groundwater, and the main reach draining each subwatershed. Hydrology of the watershed is separated into two major divisions: (a) the land phase of the hydrologic cycle and (b) the routing phase of the hydrologic cycle. The amount of water, sediment, nutrient and pesticide loadings to the main channel from each subwatershed is controlled by the land phase of the hydrologic cycle. The routing phase of the hydrologic cycle determines the movement of water, sediment and other pollutants from the channel network to the watershed outlet. All model calculations are done on a daily time scale. However, the watershed response output can be obtained at a daily to annual time scale. Aggregation of input data can be facilitated using a GIS interface available with the model. The ArcView interface developed for the SWAT model was used to prepare input files for this study. This interface requires land use/land cover, soils and DEM data as spatial inputs (Di Luzio et al., 2002). A detailed description of the model can be obtained from Neitsch et al. (2000).

\section{Description of watershed and available data}

Moores Creek watershed is a sub-basin of the Illinois River basin and is an 1890-ha agricultural watershed located in western Washington County in Northwest Arkansas, USA (Figure 1). Moores Creek feeds Lincoln Lake which serves as the secondary drinking water supply to the city of Lincoln. Major land uses within the watershed are pasture (55\%) and mixed forests (39\%). Animal production is prevalent, in the form of numerous poultry and beef operations located in the watershed. Water quality degradation of the lake can be at least partially attributed to runoff of nutrients from surface-applied animal manure in the watershed (Edwards et al., 1996, 1997).

Detailed hydrology and water quality data collected between 1997 and 2000 for the Moores Creek were used in this study. Continuous stage and flow data and water quality data of nitrate-nitrogen $\left(\mathrm{NO}_{3}-\mathrm{N}\right)$, ammonia- $\mathrm{N}$ $\left(\mathrm{NH}_{4}-\mathrm{N}\right)$, total Kjeldahl $\mathrm{N}(\mathrm{TKN})$, phosphate-phosphorus $\left(\mathrm{PO}_{4}-\mathrm{P}\right)$, total-P (TP) and total suspended solids (TSS) were available at 30-min intervals during the rising limb and 60-min intervals during the falling limb 


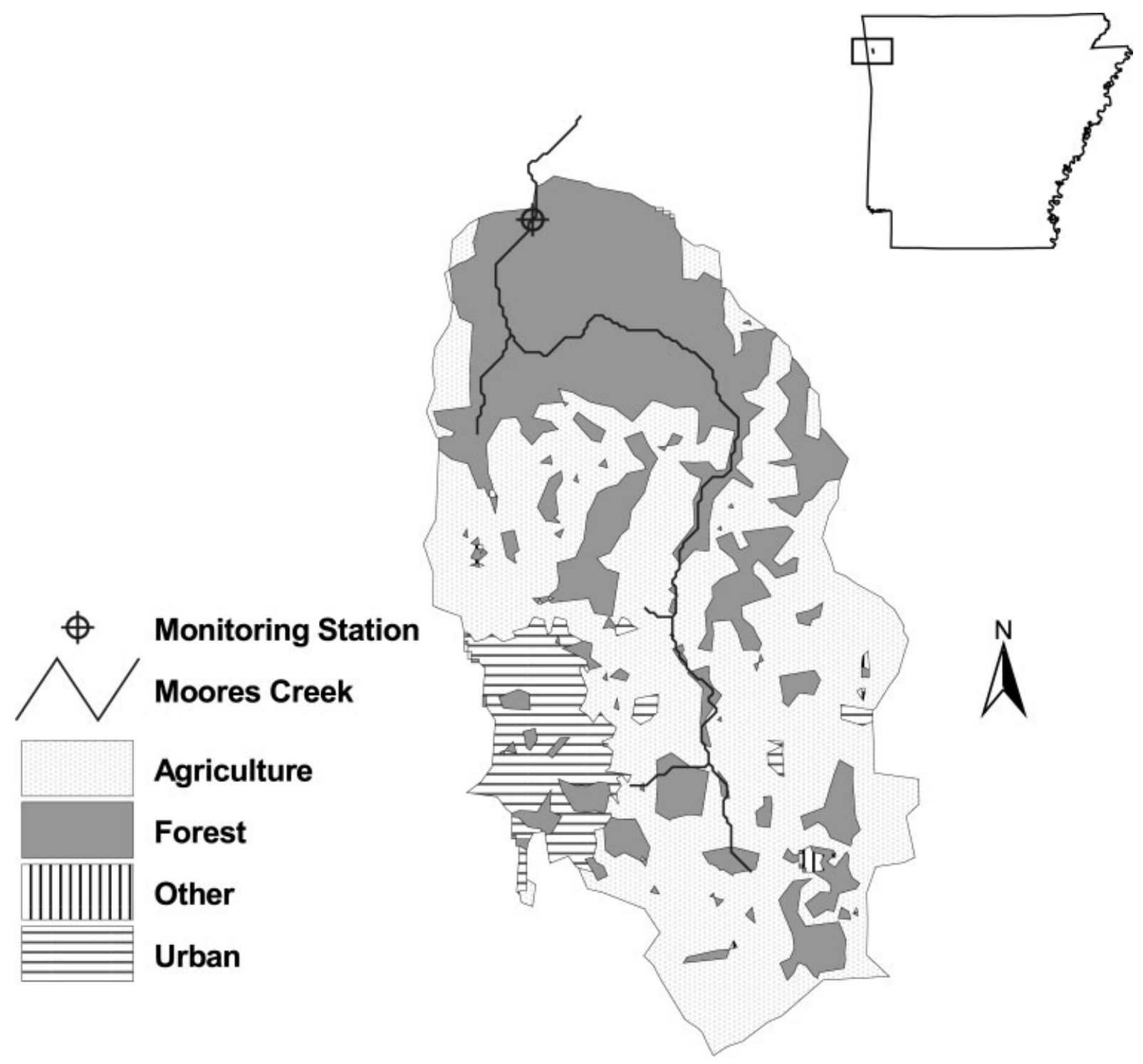

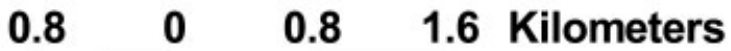

Figure 1. Location and land use of the Moores Creek watershed

of storm hydrographs, and at 14-day intervals during base flow conditions (Nelson et al., 2001). Table I shows a summary of the measured stream flow and water quality data for the watershed.

A detailed digital soil map for the watershed was obtained from the University of Arkansas Soil Physics Laboratory. The DEM for the watershed was downloaded from the United States Geological Survey. Both of these maps are scaled $1: 24000$, which is approximately $30 \times 30 \mathrm{~m}$ in horizontal resolution. Land use and land cover data for 1999 at $30 \times 30 \mathrm{~m}$ horizontal resolution, road network and stream network data in GIS format were obtained from the Center for Advanced Spatial Technology (CAST) at the University of Arkansas. 
Table I. Measured data (average annual) from the Moores Creek watershed

\begin{tabular}{lcccccc}
\hline Year & Flow $\left(\mathrm{m}^{3}\right)$ & $\mathrm{NO}_{3}-\mathrm{N}(\mathrm{kg})$ & $\mathrm{NH}_{4}-\mathrm{N}(\mathrm{kg})$ & $\mathrm{TKN}(\mathrm{kg})$ & $\mathrm{TP}(\mathrm{kg})$ & $\mathrm{PO}-\mathrm{P}(\mathrm{kg})$ \\
\hline 1997 & 2980048 & 3555 & 342 & 5865 & 1748 & - \\
1998 & 5885339 & 8218 & 494 & 8318 & 3319 & - \\
2000 & 2184249 & 4364 & 227 & 3136 & 1452 & 613 \\
\hline
\end{tabular}

\section{Model output uncertainty due to DEM spatial resolution}

The outputs considered for this analysis included flow, $\mathrm{NO}_{3}-\mathrm{N}$ and TP loads in the Moores Creek. The SWAT model parameters that affected these outputs were calibrated using measured hydrologic and water quality data for 1997 (Table I). The model was calibrated first for annual flow, including total flow, storm flow and base flow of the stream. The objective function used in model calibration was relative error (RE), defined as follows:

$$
\mathrm{RE}(\%)=\frac{(\mathrm{O}-\mathrm{P})}{\mathrm{O}} \times 100
$$

where $\mathrm{O}$ was the measured output and $\mathrm{P}$ was the SWAT predicted output. The procedure outlined in the SWAT model user's manual (Neitsch et al., 2000) was followed to adjust model parameters during the calibration process. The parameters adjusted were: (1) curve number $(\mathrm{CN})$; (2) threshold depths of water in the aquifer for revaporation to occur; and (3) threshold depths of water in the aquifer for return flow to occur. Manning's $n$ was also changed to reflect land cover in the watershed, using $0 \cdot 014$ for channel flow and $0 \cdot 14$ for overland flow (Haan et al., 1994).

After flow calibration, the model was calibrated for nutrient load predictions. The presence of numerous poultry production facilities is believed to be the source of nutrients in the watershed. The location of poultry houses in the watershed was obtained from 2000 CAST data, and verified through ground-truthing. This information was used to locate and estimate poultry litter applications and initial soil nutrient content. It was assumed that poultry litter was applied in all existing pasture areas. The litter application rate was estimated to be $5600 \mathrm{~kg} / \mathrm{ha}$ /year (Washington Country Conservation District, personal communications). This annual load was partitioned into two applications at six-month intervals. Calibration of the nutrient component of the stream flow was more difficult because changing one parameter affected all simulated loads. During the model calibration, the sum of absolute values of RE for $\mathrm{NO}_{3}-\mathrm{N}$ and TP predictions was calculated and minimized. The model parameters that were adjusted to calibrate nutrient output were average slope length, $\mathrm{N}$ and $\mathrm{P}$ percolation coefficients, and $\mathrm{P}$ soil partitioning coefficient. The calibrated model parameters resulted in a total $\mathrm{RE}$ of $15 \%$ for $\mathrm{NO}_{3}-\mathrm{N}$ and TP predictions.

After the model was calibrated using $30 \times 30 \mathrm{~m}$ input data spatial resolution, the uncertainty in the SWAT output due to spatial resolution of input DEM data was quantified by running the model at the seven DEM resolutions $(30 \times 30 \mathrm{~m}, 100 \times 100 \mathrm{~m}, 150 \times 150 \mathrm{~m}, 200 \times 200 \mathrm{~m}, 300 \times 300 \mathrm{~m}, 500 \times 500 \mathrm{~m}$, $1000 \times 1000 \mathrm{~m}$ ) for all storm events and base flow conditions for the period 1997-2000. DEM at lower resolutions was obtained by resampling the DEM data at $30 \times 30 \mathrm{~m}$ resolution using bilinear interpolation. In this interpolation scheme, the new value of a cell is based upon a weighted distance average of the four nearest input cell numbers. Flow, $\mathrm{NO}_{3}-\mathrm{N}$ and TP were the model outputs of interest. Flow and $\mathrm{NO}_{3}-\mathrm{N}$ were calculated directly by SWAT. Total $\mathrm{P}$ was estimated as the sum of organic P and mineral P. Uncertainty in the model output was quantified as RE, defined by Equation (1). Outputs obtained using $30 \times 30 \mathrm{~m} \mathrm{DEM}$ data were considered the best model outputs and were used to compare the RE from other DEM resolutions.

\section{RESULTS AND DISCUSSION}

The SWAT model delineates a watershed using DEM data and divides the resulting watershed into hydrologic response units (HRUs) using land use and soils information. The HRUs are areas within a watershed having 
similar hydrologic properties and are used to delineate subwatersheds. The effect of input DEM data resolution on delineated watershed area, number of subwatersheds and number of HRUs is shown in Table II. If we consider the $30 \times 30 \mathrm{~m}$ DEM data to give the best estimate of the watershed properties, Table II shows that all other DEM resolutions resulted in slightly different watershed delineation and watershed area. The effect was most significant for $500 \times 500 \mathrm{~m}$ and $1000 \times 1000 \mathrm{~m}$ resolution, where the error (deviation from the $30 \times 30 \mathrm{~m}$ resolution) in estimated watershed area was $14 \%$ and $31 \%$, respectively. Errors in the watershed area at other DEM resolutions ranged from less than $1 \%(100 \times 100 \mathrm{~m})$ to $4 \%(300 \times 300 \mathrm{~m})$. The SWAT delineated watershed boundary, subwatersheds and stream network for three DEM resolutions are shown in Figure 2. The watershed and stream network representation became increasingly less accurate with decrease in DEM resolution. Since the watershed area directly influences the amount of runoff volume, total sediment and total nutrients generated within a watershed, a large error in the watershed area delineated can be expected to result in a large error in the predicted output. Similarly, the numbers of HRUs and subwatersheds were also affected by the DEM resolution, possibly due to differences in watershed and stream network delineation by the SWAT model. Table II shows that number of HRUs within the watershed increased for $100 \times 100 \mathrm{~m}$ and $200 \times 200 \mathrm{~m}$ DEM resolution, and decreased for other DEM resolutions, respectively. The numbers of subwatersheds for each DEM data resolution, except for $200 \times 200 \mathrm{~m}$, were also different compared to $30 \times 30 \mathrm{~m}$ DEM resolution. Since runoff is predicted at the HRU level within each subwatershed and then routed to get total runoff for the watershed (Neitsch et al., 2000), the difference in numbers of HRUs and subwatersheds at different DEM resolutions may result in loss of important information on watershed heterogeneity and may result in increased output uncertainty.

The model predictions for flow, $\mathrm{NO}_{3}-\mathrm{N}$ and $\mathrm{TP}$ loads were compared to the predictions at the calibrated DEM resolution $(30 \times 30 \mathrm{~m})$. Table III shows the average of total annual predicted values for each output. The effect of DEM data resolution on model output was measured using RE from Equation (1). Figure 3 shows how RE for each parameter was affected by data resolution for 1997.

In general the results show that as the DEM horizontal resolution became coarser, the predicted stream flow volume decreased. Coarser resolutions reduce the heterogeneity of the topography. A reduced DEM resolution resulted in a smaller stream slope and longer slope lengths within the watershed, and when combined with
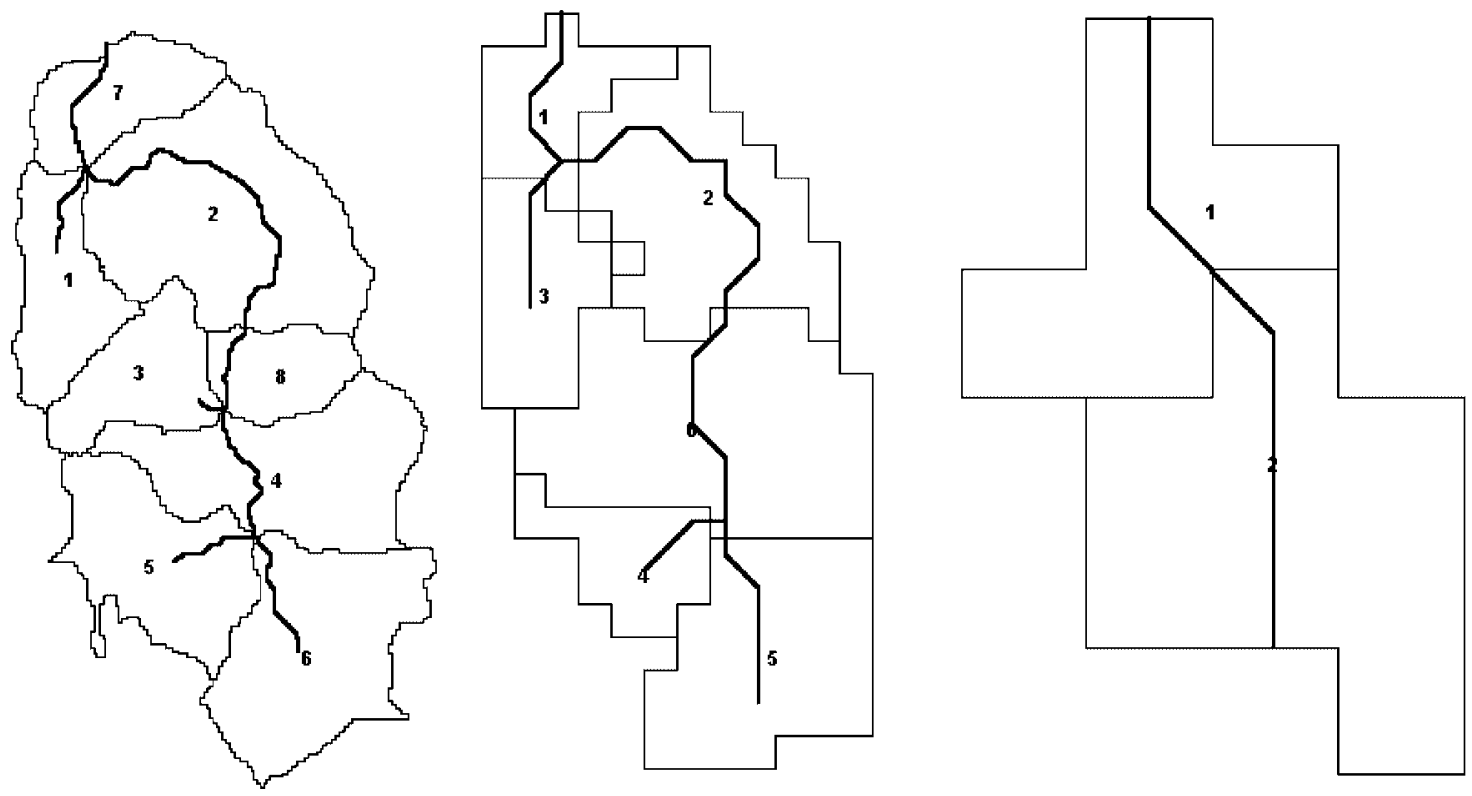

Figure 2. SWAT watershed delineation shown at $30 \mathrm{~m}, 300 \mathrm{~m}$ and $1000 \mathrm{~m}$ (from left to right) 


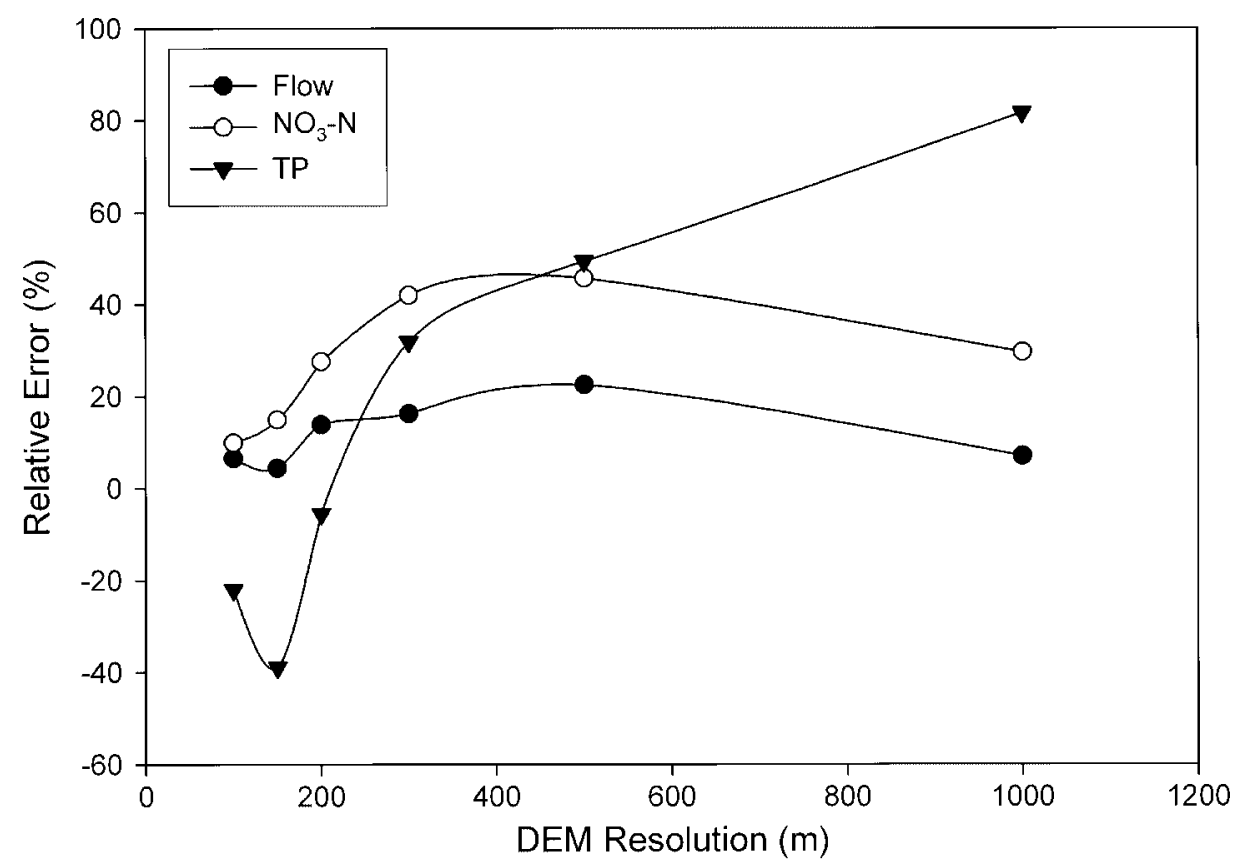

Figure 3. Relative error (RE) in SWAT model output for flow, $\mathrm{NO}_{3}-\mathrm{N}$ and TP for 1997

Table II. Effect of input DEM resolution on delineated watershed properties

\begin{tabular}{lccc}
\hline $\begin{array}{l}\text { DEM } \\
\text { resolution }\end{array}$ & $\begin{array}{l}\text { Watershed } \\
\text { area (ha) }\end{array}$ & $\begin{array}{c}\text { Number of } \\
\text { subwatersheds }\end{array}$ & $\begin{array}{c}\text { Number of } \\
\text { HRUs }\end{array}$ \\
\hline $30 \times 30 \mathrm{~m}$ & 1887 & 8 & 59 \\
$100 \times 100 \mathrm{~m}$ & 1871 & 10 & 66 \\
$150 \times 150 \mathrm{~m}$ & 1879 & 10 & 69 \\
$200 \times 200 \mathrm{~m}$ & 1840 & 8 & 72 \\
$300 \times 300 \mathrm{~m}$ & 1818 & 6 & 49 \\
$500 \times 500 \mathrm{~m}$ & 1625 & 6 & 38 \\
$1000 \times 1000 \mathrm{~m}$ & 1300 & 2 & 11 \\
\hline
\end{tabular}

Table III. Average SWAT model predictions at varying DEM resolutions (1997-2000)

\begin{tabular}{|c|c|c|c|c|c|c|}
\hline \multirow[t]{2}{*}{ Scale } & \multicolumn{2}{|c|}{ Stream flow } & \multicolumn{2}{|c|}{$\mathrm{NO}_{3}-\mathrm{N}$} & \multicolumn{2}{|c|}{$\mathrm{TP}$} \\
\hline & Average $\left(\mathrm{m}^{3}\right)$ & $\operatorname{RE}(\%)$ & Average (kg) & $\mathrm{RE}(\%)$ & Average (kg) & $\mathrm{RE}(\%)$ \\
\hline $30 \times 30 \mathrm{~m}$ & 5130052 & 0 & 4350 & 0 & 2041 & 0 \\
\hline $100 \times 100 \mathrm{~m}$ & 4930139 & 5 & 3860 & 10 & 2517 & 22 \\
\hline $150 \times 150 \mathrm{~m}$ & 4926904 & 4 & 3539 & 18 & 2891 & 40 \\
\hline $200 \times 200 \mathrm{~m}$ & 4685099 & 10 & 3038 & 30 & 2178 & 6 \\
\hline $300 \times 300 \mathrm{~m}$ & 4493075 & 13 & 2449 & 44 & 1459 & 29 \\
\hline $500 \times 500 \mathrm{~m}$ & 3830616 & 25 & 2103 & 51 & 1020 & 50 \\
\hline $1000 \times 1000 \mathrm{~m}$ & 4077944 & 17 & 2515 & 40 & 360 & 82 \\
\hline
\end{tabular}


smaller watershed area, resulted in less flow volume. The same trend was seen in the $\mathrm{NO}_{3}-\mathrm{N}$ predictions. This trend was seen at all DEM resolutions. Predicted values for each individual year also showed that stream flow and $\mathrm{NO}_{3}-\mathrm{N}$ were underestimated when input DEM resolution decreased. The range of $\mathrm{RE}$ for stream flow was $4-25 \%$ and for $\mathrm{NO}_{3}-\mathrm{N}$ was $10-51 \%$, respectively (Table III). The total RE, defined as the sum of individual REs, ranged from $45-140 \%$. The results from this study show that the choice of input DEM resolution for the SWAT model applications depends on the output of interest. If only the stream flow response is to be modelled, a DEM resolution up to $200 \times 200 \mathrm{~m}$ will result in less than $10 \%$ RE in model predictions. If $\mathrm{NO}_{3}-\mathrm{N}$ is the output of interest, then an input resolution of less than $100 \times 100 \mathrm{~m}$ is needed to achieve a similar level of accuracy in SWAT predictions.

Contrary to the results obtained for stream flow and $\mathrm{NO}_{3}-\mathrm{N}$ export, a decrease in DEM data resolution did not always result in decreased TP export. In fact, the predicted TP losses increased when $100 \times 100 \mathrm{~m}$, $150 \times 150 \mathrm{~m}$ and $200 \times 200 \mathrm{~m}$ DEM data was used, and decreased for other DEM data resolutions. A minimum RE for TP predictions $(6 \%)$ was obtained using $200 \times 200 \mathrm{~m}$ input data resolution. All other DEMs resulted in a higher RE in TP predictions (Figure 3).

Results from this study are similar to the results reported for other models and for other DEM resolutions for the SWAT model. In a study done using 71 different watersheds and TOPMODEL, Wolock and Price (1994) found that increasing DEM coarseness from $30 \times 30 \mathrm{~m}$ to $90 \times 90 \mathrm{~m}$ increased runoff prediction by decreasing slope and increasing slope area per unit contour length. In a different study involving the SWAT model, Cho and Lee (2001) found that simulated runoff was higher for $30 \times 30 \mathrm{~m}$ data resolution compared to runoff volume predicted using $90 \times 90 \mathrm{~m}$ DEM. The authors surmised that a finer data resolution resulted in higher slope and hence the higher simulated runoff volume. Uncertainty in the SWAT model predictions is also affected by resolution of other input GIS data such as land use and soils, and is reported by Cotter et al. (2003).

\section{SUMMARY AND CONCLUSIONS}

Watershed topography is an important factor in determining watershed response to runoff and water quality parameters. In this study, the effect of DEM data resolution on SWAT model output uncertainty was evaluated. Measured hydrologic, meteorological, watershed characteristics and water quality data from Moores Creek watershed were used in the simulation. The effect of DEM spatial resolution was evaluated by running seven scenarios at increasing horizontal scales $(30 \times 30 \mathrm{~m}, 100 \times 100 \mathrm{~m}, 150 \times 150 \mathrm{~m}, 200 \times 200 \mathrm{~m}, 300 \times 300 \mathrm{~m}$, $500 \times 500 \mathrm{~m}$, and $1000 \times 1000 \mathrm{~m})$. A $30 \times 30 \mathrm{~m}$ input DEM data resolution was used to calibrate the model on an annual basis for stream flow, $\mathrm{NO}_{3}-\mathrm{N}$ and total $\mathrm{P}$. The predicted output at the calibrated scale was used to evaluate output accuracy for the remaining input resolutions. Input DEM data resolution affected SWAT model predictions by affecting total area of the delineated watershed, predicted stream network and sub-basin classification. Lower values of stream flow and $\mathrm{NO}_{3}-\mathrm{N}$ were predicted when a coarser DEM data was input, probably due to decrease in total watershed area and watershed slope, and increased slope length. However, this result was not consistent with TP predictions. Results of this study indicate that the choice of input DEM data resolution for the SWAT model depends on the output of interest. Since the use of the SWAT model in making watershed response predictions can be expected to increase in future, every effort must be made to collect and input DEM data at a finer resolution to minimize uncertainties in the model predictions.

\section{ACKNOWLEDGEMENTS}

The authors acknowledge the funding provided by the USGS through Arkansas Water Resources Center (Grant Number 01HQGR0076) and Arkansas Experiment Station as the contribution to the Southern Regional Research Project S-1004. Sincere thanks are extended to Ms Kati White for providing help with the SWAT model simulations and Dr H. D. Scott for compiling the soils data. 


\section{REFERENCES}

Arnold JG, Allen PN, Bernhardt G. 1993. A comprehensive surface-groundwater flow model. Journal of Hydrology 142: 47.

Arnold JG, Srinivasan R, Muttiah RS, Williams JR. 1998. Large area hydrologic modeling and assessment. Part 1. Model development. Journal of the American Water Resources Association 34(1): 1-17.

Chaubey I, Haan CT, Salisbury JM, Grunwald S. 1999. Quantifying model output uncertainty due to spatial variability of rainfall. Journal of the American Water Resources Association 35(5): 1113-1123.

Cho SM, Lee MW. 2001. Sensitivity considerations when modeling hydrologic processes with digital elevation model. Journal of the American Water Resources Association 37(4): 931-934.

Cotter AS, Chaubey I, Costello TA, Soerens TS, Nelson MA. 2003. Water quality model output uncertainty as affected by spatial resolution of input data. Journal of the American Water Resources Association 39: 977-986.

Di Luzio MD, Srinivasan R, Arnold JG. 2002. Integration of watershed tools and SWAT modeling into BASINS. Journal of the American Water Resources Association 38(4): 1127-1142.

Edwards DR, Daniel TC, Scott HD, Murdoch JF, Habiger MJ, Burks HM. 1996. Stream quality impact of best management practices in a Northwest Arkansas Basin. Journal of the American Water Resources Association 32(3): 499-509.

Edwards DR, Daniel TC, Scott HD, Moore PA Jr, Murdoch JF, Vendrell PF. 1997. Effect of BMP implementation on storm flow quality of two Northwest Arkansas streams. Transactions of the ASAE 40(5): 1311-1319.

Faures J, Goodrich DC, Woolhiser DA, Sorooshian S. 1995. Impact of small-scale spatial variability on runoff modeling. Journal of Hydrology 173: 309-326.

Goodrich DC, Faures J, Woolhiser DA, Lane LJ, Sorooshian S. 1995. Measurement and analysis of small-scale convective rainfall variability. Journal of Hydrology 173: 283-308.

Haan CT, Barfield BJ, Hayes JC. 1994. Design Hydrology and Sedimentology for Small Catchments. Academic Press: San Diego, CA.

Inskeep WP, Wraith JM, Wilson JP, Snyder RD, Macur RE, Gaber HM. 1996. Input parameter and model resolution effects on predictions of solute transport. Journal of Environmental Quality 25: 453-462.

Moore ID, Grayson RB, Landson AR. 1991. Digital terrain modeling: a review of hydrological, geomorphological, and biological application. International Journal of Hydrological Process 5(1): 3-30.

Neitsch SL, Arnold JG, Kiniry JR, Williams JR. 2000. Soil and Water Assessment Tool User's Manual. Blackland Research Center: Temple, TX.

Nelson MA, Soerens TS, Spooner J. 2001. Investigation of optimum sample number and timing for determining storm water pollutant loads [Year 1998 and 1999]. Arkansas Water Resources Center Annual Report 1999-2000.

Piwowar J, LeDrew EF. 1990. Integrating spatial data: a user's perspective. PE\&RS 56(11): 1497-1502.

Shah SMS, O'Connell PE, Hosking JRM. 1996. Modeling the effect of spatial variability in rainfall on catchment response. 1. Formulation and calibration of a stochastic rainfall field model. Journal of Hydrology 175: 67-88.

Troutman BM. 1983. Runoff prediction errors and bias in parameter estimation induced by spatial variability of precipitation. Water Resources Research 19(3): 791-810.

Wagenet RJ, Hutson JL. 1996. Scale-dependency of solute transport modeling/GIS applications. Journal of Environmental Quality 25: 499-510.

Wilson JP, Inskeep WP, Wraith JM, Snyder RD. 1996. GIS-based solute transport modeling applications: scale effects of soil and climate data input. Journal of Environmental Quality 25: 445-453.

Wolock DM, McCabe GJ Jr. 1995. Comparison of single and multiple flow direction algorithms for computing topographic parameters in TOPMODEL. Water Resources Research 31(5): 1315-1324.

Wolock DM, Price CV. 1994. Effects of digital elevation model map scale and data resolution on topography-based watershed model. Water Resources Research 30(11): 3041-3052. 